\title{
During Disaster: Refining the Concept of Focusing Events to Better Explain Long-Duration Crises
}

Rob A. DeLeo, Kristin Taylor, Deserai A. Crow and Thomas A. Birkland

\section{(2) OpenEdition \\ Journals}

Electronic version

URL: https://journals.openedition.org/irpp/1868

DOI: $10.4000 /$ irpp. 1868

ISSN: 2706-6274

Publisher

International Public Policy Association

Printed version

Date of publication: 15 March 2021

ISSN: 2679-3873

Electronic reference

Rob A. DeLeo, Kristin Taylor, Deserai A. Crow and Thomas A. Birkland, "During Disaster: Refining the Concept of Focusing Events to Better Explain Long-Duration Crises", International Review of Public Policy [Online], 3:1 | 2021, Online since 15 March 2021, connection on 17 June 2021. URL: http:// journals.openedition.org/irpp/1868; DOI: https://doi.org/10.4000/irpp.1868

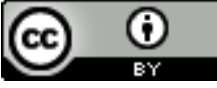




\title{
During Disaster: Refining the Concept of Focusing Events to Better Explain Long-Duration Crises
}

\author{
Rob A. DeLeo
}

Bentley University, USA

\section{Kristin Taylor}

Wayne State University, USA

\section{Deserai A. Crow}

University of Colorado Denver, USA

\section{Thomas A. Birkland}

North Carolina State University, USA

\section{Abstract}

Potential focusing events are sudden, relatively rare events that reveal harm, or the potential for harm, are known to policymakers and the public virtually simultaneously, and work harms on a definable geographic area or community of interest. Focusing events can provide a powerful symbol of government failure, thereby allowing previously ignored issues to advance on the government agenda. We revisit this conceptualization of focusing events within the context of the COVID-19 pandemic. We show that, while the current COVID-19 pandemic has had a profound effect on both the media and government agendas, it lacks many of the elements used to differentiate focusing events from other theoretical constructs used to describe public problems. Specifically, our findings suggest that focusing event theory is ill equipped to describe slow-onset, long-duration disasters such as COVID-19. We develop a new typology for characterizing these types of events, which accounts for both the duration of the event as well as the magnitude or scale of the event's impact.

\section{Keywords}

focusing events, agenda setting, policy change, COVID-19 


\section{Introduction}

The COVID-19 pandemic is one of the most significant public health crises in modern history, killing over 2 million people worldwide (Johns Hopkins, 2021). Unsurprisingly, a chorus of popular commentators has come to label it a "focusing event" capable of yielding broad social and political change across virtually every sector of society (Jenkins, 2020; Reville, 2020; Burgess, 2020; Olshan, 2020; Zenko, 2020). Jeremy Olshan (2020) of MarketWatch writes: "Social scientists say a crisis like COVID-19 is a 'focusing event', one that recalibrates public policy and cultural norms. This collective focusing may not happen quickly enough." Micah Zenko, Senior Fellow at Chatham House, writing in Foreign Policy, said "the virus offers a focusing event from which political leaders and government officials can have a (roughly) shared understanding of what happened, why it happened, who is accountable, and how can it be avoided". And in his Boston Globe op-ed, Harvard Professor of Education Paul Reville (2020) calls the pandemic a "focusing event that has turned public attention to children and education".

This line of thinking has permeated academic publishing as well. A simple Google Scholar search unearths scores of peer-reviewed publications labelling the pandemic a focusing event. This research suggests that the pandemic has facilitated opportunities for policy change not only within the public health community (Hur \& Kim, 2020), but in scores of other policy areas as well, including long-term care policy (Béland \& Marier, 2020; Reynolds, 2020), labor and delivery policy (Monteblanco, 2021), education policy (Hoffman \& Miller, 2020), immigration policy (Jakobson \& Kalev, 2020), healthcare finance policy (Béland et al., 2020), and housing policy (Verhaeghe \& Ghekiere, 2020).

While few would object to calling COVID-19 a crisis, a closer reading of extant policy theory suggests that the current pandemic lacks many of the key features typically associated with potential focusing events. It was neither sudden nor unexpected by experts. It was not geographically isolated. And, to date, it is largely unclear whether the crisis will trigger the types of large-scale policy changes potentially associated with learning from focusing events (Birkland, 1997, 1998). Complicating matters further, many of the crises explored in the focusing events literature tend to be time-bound disasters, such as earthquakes, hurricanes, or technological accidents. By contrast, the COVID-19 pandemic is a slow-onset, long-duration phenomenon that has caused - and will continue to cause and reveal - harms over a long time.

Within this context the following study assesses whether COVID-19 has the characteristics of a focusing event. We begin by reviewing the existing research on focusing events. Although the concept has been widely applied across the policy sciences, our analysis is grounded in Birkland's $(1997,1998)$ conceptualization of potential focusing events, which focuses on agenda setting and policy change after man-made or naturally occurring disaster. We use a mixedmethods design to analyze the extent to which COVID-19 can be accurately characterized as a focusing event, its influence on the agenda of the United States Congress and the U.S. national media, and the extent to which the pandemic has induced policy change. We show that, while the current crisis has a profound effect on legislative and media agendas, it does not meet the classic definition of a focusing event, and therefore has different effects on agenda-setting and the development of policy solutions that are typically seen in event-driven policy. Nor has it yet sparked robust lesson-learning that can be applied to similar hazards in the future. We conclude by presenting a typology for characterizing the policymaking implications of slow-onset, long-duration events such as the COVID-19 pandemic. 


\section{Focusing Events and Policy Process Theory}

The term "focusing event" was coined by John Kingdon in his 1984 book Agendas, Alternatives, and Public Policy, which forms the foundation of the Multiple Stream Framework (MSF) of agenda setting and policy change. The MSF argues that the policy process contains three streams of activity, which, when coupled, create windows of opportunity for proponents of policy change to push their favored issues onto the crowded government agenda (Herweg et al., 2017). The policy stream includes policies presented as solutions to pressing social issues. The politics stream describes the partisan composition of government, interest-group preferences, and the national mood, which refers to the way in which elected officials perceive the preferences of the public. Finally, the problem stream describes the various items vying for policymaker attention.

Focusing events represent an important element of the problem stream, along with indicators and feedback. Indicators are statistics and other measures documenting changes in a problem. Feedback includes information generated through evaluations of existing government programs. But these aspects of policy problems are often insufficient to generate attention. Rather, Kingdon argues that "problems...need a little push to get the attention of people in and around government". Pushes come in the form of a focusing event or a "crisis or disaster that comes along to call attention to the problem, a powerful symbol that catches on, or the personal experience of a policy maker" (2003, pp. 94-95).

\section{Focusing Events Defined}

Kingdon's definition of focusing events is imprecise, discursive, and inductive. Birkland (1997) clarifies the concept to make it more tractable to systematic study. He defines potential focusing events as "sudden, relatively rare, can be reasonably defined as harmful or revealing the possibility of future harms, inflicts harms or suggests potential harms that are or could be concentrated on a definable geographical area or community of interest, and that is known to policy makers and the public virtually simultaneously" (Birkland, 1997, p. 22). This refinement allows us to measure the features of an event that makes it "focal," such as the suddenness of the event, harms (e.g., injuries, deaths, property damage) from the event, and the scope of the disaster (e.g., population of the area affected or the size of the group affected by the event). Birkland's emphasis on a potential event suggests that it is difficult to know a priori whether an event will have a great deal of focal power.

By sharpening and clarifying the definition of a focusing event, Birkland's theory offers an understanding of the concept that is more measurable but slightly narrower than the definitions offered by rival theories. The Advocacy Coalition Framework (ACF), for example, suggests that so-called "external shocks" encompass not only disasters, but other types of events as well, such as shifts in public opinion, or even deteriorating socioeconomic conditions (e.g., a recession) (Jones \& Jenkins-Smith, 2009; Jenkins-Smith et al., 2017; Nohrstedt, 2009). Punctuated Equilibrium Theory (PET) has allowed for a fairly sweeping conceptualization of focusing events or exogenous shocks (Baumgartner \& Jones, 2009), one which includes disasters as well as important social and political developments, such as important court rulings (Wood, 2006).

Still, Birkland's (1997) study remains the gold-standard among students of disaster policy, a testament to his careful operationalization and measurement of the concept. Existing applications have focused primarily on sudden-onset events, such as aviation security incidents (Birkland, 2004), flooding (O’Donovan, 2017; Albright \& Crow, 2021), wildfires (Crow et al, 2017), hurricanes (Roberts, 2009), and earthquakes (DeYoung \& Penta, 2017). In contrast, 
scholarship on emerging diseases, which gradually unfold over a period of weeks or months, has primarily focused on the role of indicators to initiate issue attention (DeLeo, 2018). Well before the COVID pandemic, Birkland (2006) used the avian influenza outbreak to highlight this distinction:
In 2005, for example, the problem of the H5N1 strain of bird flu influenza gained worldwide attention, and its transmission to humans in Turkey and Europe in early 2006 has increased concern about pandemic flu, and in particular about the possibil- ity of its transmission from person to person rather than from birds to people. But a global flu pandemic is a different kind of disaster from the type described in this book because it can be anticipated before the pandemic occurs (p.7).

He adds that, in public health domains, "problems become known slowly, as indicators of problems accumulate and become more evident" (p. 7). This is not to say that public health matters do not come to occupy a great deal of the agenda; rather, that public health issues emerge on the agenda over time, not in an instant. Nor are we arguing that pandemics cannot emerge quickly; we are arguing that they do not emerge suddenly, in a way that causes the mass public and policy elites to come to the "alarmed discovery" (Downs, 1972) of a problem nearly simultaneously.

With this in mind, there does not appear to be a bright line between focusing events and indicators. Research suggests that, when indicators amass rapidly, providing little time for policymakers to engage in the type of pre-event preparedness typically associated with public health domains, events can bowl their way onto the government agenda in much the same way as a focusing event (DeLeo, 2015; DeLeo, 2018). For example, unlike the 2005 avian influenza case described by Birkland, a number of recent public health crises, including the 2009 swine influenza pandemic and the 2014 Ebola epidemic, escalated relatively quickly, sickening and killing thousands of people in a matter of months. This revelation of harms is thus much more akin to the dramatic shock caused by a sudden-onset event than the long, drawn-out process typically associated with the gradual accumulation of indicators (see also DeLeo, 2021).

\section{Focusing Events, Issue Attention and Agenda Change}

Focusing events are important in the policy process because they can open windows of opportunity for elevating issues onto the agenda. Kingdon (2003) suggests that disasters have the ability to "simply bowl over everything standing in the way of prominence on the agenda" (p. 96). Birkland's notion of potential focusing events tempers this expectation by showing that many disasters fail to trigger the type of robust mobilization typically associated with agenda change and that, in any case, we cannot know a priori whether an event will have very much "focal" power. While most disasters trigger an uptick in negative media and policymaker attention, agenda change occurs when events induce government to explore potential actions in the face of the policy failures revealed by the event. Moreover, research suggests that single, one-off events tend not to open windows of opportunity (O'Donovan, 2017). Instead, windows open due to an accumulation of experience with the problems revealed by events over time. The accumulated experience of nearby jurisdictions may also influence policy change during relatively brief windows of time (O’Donovan, 2017).

However, some conditions can make focusing events more powerful and influential than other events. First, the suddenness of an event, and concomitant claims that the event was unforeseeable, are consistently influential. By moving the harms of an event from the realm of the foreseeable - or, more to the point, the preventable - to the realm of the unexpected, the 
policy actors responsible for addressing the problems raised by a focusing event can shift culpability from human frailty to chance occurrence (Stone, 1989). Second, the severity or widespread nature of an event can also catalyze policy change, either out of necessity or due to lessons learned from the event (Crow et al., 2019). Third, the framing of the issues revealed by the event helps to define the underlying problems that exist, thereby narrowing the scope of possible policy solutions (Lawlor \& Crow, 2018; Crow et al., 2016; Wolfe et al., 2013; 't Hart \& Tindall, 2009; Lawrence \& Birkland, 2004). Finally, the institutional arrangements within a policy domain are important for issue attention. Agency characteristics, the statutory or regulatory regime in place, and the extent to which the policy problem is discrete or spans several policy areas, can be highly influential in shaping issue attention within the domain (May et al., 2009; May et al., 2008).

\section{Focusing Events and Policy Change}

Focusing events can help to induce agenda change; however, not all events promote what we might normatively believe to be the "correct" kind of policy change. For example, school shootings focus attention and capture agenda space but do not often lead to policy change. This is because, for some highly conflictual policy issues, increased attention to the problem on the agenda may mean that policy entrepreneurs seek to flood the policy debate with their preferred construction of the problem and its solutions in an effort to deny agenda space to other actors (Wolfe et al., 2013; Pralle, 2009; Wheeldon \& McBrien, 2015; Lawrence \& Birkland, 2004).

Birkland's conception of focusing events shares similarities with Anthony Downs's Issue-Attention cycle (1972), in which an event causes a very sudden increase in concern about a problem, followed by a decline in interest in the problem as the benefits and the costs of potential solutions become manifest while the "alarmed discovery" of the problem wanes over time. Unlike Downs, however, Birkland's conception of focusing events indicates that events can yield policy change that creates long-term institutional and attitudinal change in relation to public problems. In the case of the Exxon Valdez oil spill, the focusing event overcame a lengthy legislative deadlock and led to the enactment of the Oil Pollution Act of 1990, which substantially changed prevention and response policy regarding oil spills, while the September 11 attacks led, among other things, to significant changes in the aviation security system worldwide (Birkland, 2004).

As focusing events reveal policy failure, they can prompt learning about why the event happened, what can be done to respond to it, and what can be done to prevent its recurrence (McConnell, 2010a). Policy learning describes the process through which policymakers apply new information and ideas to policy decisions and is one of the most important pathways to policy change (Sabatier \& Jenkins-Smith, 1999; May, 1992). Disasters reveal deficiencies in existing policy regimes, in turn providing an opportunity for the government to reexamine old laws and enact changes to mitigate risk (Birkland, 2006; Albright, 2011; Albright \& Crow, 2021; Crow \& Albright, 2019; O’Donovan, 2017; Heikkila \& Gerlak, 2013).

There are various types of post-event learning (May, 1992). Instrumental learning focuses on the utility of existing policy instruments or the tools used to achieve program objectives. Social learning focuses not on the intricacies of policy design, but on the way in which problems are framed and defined and the underlying causes of problems. Between these two are various types of learning that can lead to changes in organizations, policies, and strategies used to accomplish policy goals (May, 1992; Birkland, 2006; O’Donovan, 2017). It is important to note, however, that the post-event enactment of new legislation is not evidence of instrumental or 
social learning. Many policies do little more than reinforce the status quo by simply funneling additional funding into existing institutions or programs without closely evaluating the substantive effects of existing policy (Birkland, 2004; Baumgartner \& Jones, 2009). The time horizon for policy change is, however, limited to fairly short windows of opportunity, namely the period when the public and media are focused on the disaster and on recovery from the event.

\section{Data and Methods}

To what extent is COVID-19 a focusing event? To assess this question, we use a mixed-methods design, combining quantitative analysis of the emerging-disease policy domain with a case analysis of COVID-19 policymaking in the U.S. Our quantitative analysis examines the infectious-disease policy domain from 1995 through the third quarter of 2020. We use this span of time because policy dynamics often take a decade or more to manifest and also to reflect the effects of exogenous events on government agendas (Sabatier, 1988). We estimate the effect that prominent infectious-disease outbreaks during that time, including COVID-19, influenza, Ebola, and Severe Acute Respiratory Syndrome (SARS), had on the U.S. congressional agenda and on the media agenda, as measured by mentions in the Congressional Record and the New York Times. We model COVID-19 not as a stand-alone event, but as one of a number of events influencing the larger emerging-disease domain over the last 25 years. This approach prevents us from narrowly focusing on the idiosyncrasies of the COVID-19 pandemic, which has not yet run its course. Our approach also provides several points of comparative data. The models use count data, so we rely on negative binomial analysis to estimate the effect of disease cases on the media and congressional agendas. Negative binomial regression has been previously used by scholars examining the relationship between public health issues and agenda setting (DeLeo, 2018; see also Delshad, 2012).

Our qualitative case analysis examines the similarities and differences between COVID-19 policymaking and Birkland's conceptualization of focusing events. An exploratory case-study approach of this nature is appropriate given the theoretical goals of this analysis (Yin, 2017). The quantitative model detects fairly broad patterns of issue attention and agenda change, while the case study specifically examines the process through which COVID-19 emerged as a political issue, triggered policy change, and potentially induced learning.

Table 1 provides a summary of the variables in the regression analysis. We model two dependent variables. The first dependent variable, media change, captures the number of mentions in news stories of COVID-19, Severe Acute Respiratory Syndrome (SARS), avian influenza, swine influenza, and Ebola, in the New York Times from 1995 through August 15, 2020. The data were gathered by searching the LexisNexis University database for the terms "COVID-19," "SARS," "avian influenza," "swine flu," and "Ebola" in the headlines and lead paragraphs of stories published in the New York Times, a newspaper of record in the United States and therefore a useful measure of media attention paid to major national issues and their influence on other media reporting (Weaver et al., 2004). 
Table 1: Variable Summary

\begin{tabular}{|l|l|l|l|}
\hline Name & Description & Values & Source \\
\hline Dependent Variables & \multicolumn{2}{l|}{} \\
\hline Agenda Change & $\begin{array}{l}\text { Number of Congressional } \\
\text { Record entries }\end{array}$ & $\begin{array}{l}\text { Count-data, entries } \\
\text { by quarter-year }\end{array}$ & Congress.gov website \\
\hline Media Coverage & $\begin{array}{l}\text { Number of New York Times } \\
\text { stories }\end{array}$ & $\begin{array}{l}\text { Count-data, stories } \\
\text { by quarter-year }\end{array}$ & $\begin{array}{l}\text { Lexis-Nexis online } \\
\text { database }\end{array}$ \\
\hline Independent Variables & $\begin{array}{l}\text { Number of COVID-19 } \\
\text { human cases worldwide }\end{array}$ & $\begin{array}{l}\text { Count-data, cases by } \\
\text { quarter-year }\end{array}$ & $\begin{array}{l}\text { WHO Situational } \\
\text { Reports }\end{array}$ \\
\hline COVID-19 & $\begin{array}{l}\text { Number of SARS human } \\
\text { cases }\end{array}$ & $\begin{array}{l}\text { Count-data, cases by } \\
\text { quarter-year }\end{array}$ & $\begin{array}{l}\text { WHO Situational } \\
\text { Reports }\end{array}$ \\
\hline SARS & $\begin{array}{l}\text { Number of human cases } \\
\text { resulting from the 2014 } \\
\text { Ebola epidemic }\end{array}$ & $\begin{array}{l}\text { Count-data, cases by } \\
\text { quarter-year }\end{array}$ & $\begin{array}{l}\text { WHO Situational } \\
\text { Reports }\end{array}$ \\
\hline Evian influenza & $\begin{array}{l}\text { Number of human H5N1 } \\
\text { avian influenza cases }\end{array}$ & $\begin{array}{l}\text { Count-data, cases by } \\
\text { quarter-year }\end{array}$ & $\begin{array}{l}\text { WHO Situational } \\
\text { Reports }\end{array}$ \\
\hline Ebola 2014 epidemic & $\begin{array}{l}\text { Number of human H1N1 } \\
\text { swine influenza cases }\end{array}$ & $\begin{array}{l}\text { Count-data, cases by } \\
\text { quarter-year }\end{array}$ & $\begin{array}{l}\text { WHO Situational } \\
\text { Reports }\end{array}$ \\
\hline quarter-year
\end{tabular}

Source : The Authors

The second dependent variable, agenda change, applies the same search string used to gather New York Times data but measures the number of times that emerging diseases were entered in the Congressional Record. A running record of all the statements made on the floor of the United States Congress, the Congressional Record is a widely used proxy for agenda change. Because Congress takes various recesses over the course of a given legislative session, both agenda change and media change are measured by quarter-year (every three months), yielding 103 quarters to analyze in the dataset.

Independent variables account for the number of global cases resulting from six of the largest and most significant novel-disease outbreaks since 1995. Our disease data come from the World Health Organization's (WHO) Situational Update Reports, which provide detailed accounts of the global incidences of various novel diseases. Situational Update Reports are available on the WHO website. Independent variables are count data and are measured quarterly. 
We include two variables measuring outbreaks of the novel coronavirus, COVID-19, the primary focus of this study, and SARS. Coronaviruses denote a diverse family of viruses that range in severity from the common cold to serious and often life-threatening complications such as respiratory distress. Because humans have no history of exposure to novel coronaviruses, and therefore little or no immunity, these viruses are particularly deadly. COVID-19 was first identified in China in December 2019. By March 2020, the WHO declared the outbreak a pandemic, as the disease resulted in thousands of cases worldwide. As of this writing, COVID-19 is estimated to have made more than 107 million individuals sick, killing more than 2.3 million of them. SARS made more than 8,000 people sick worldwide between November 2002 and May 2004. SARS was an extraordinarily lethal disease, and despite the lower disease incidence, it killed more than 770 people.

We include two variables measuring outbreaks of novel influenza, avian influenza and swine influenza. Novel influenza is a classification used to describe influenza viruses that cause human cases but are different from seasonal flu, which means that humans often lack immunity. The first pandemic influenza scare came in 2003 following the outbreak of a novel strain of H5N1 avian influenza in Southeast Asia. The outbreak was contained, never infecting more than 120 people a year. In contrast, the $2009 \mathrm{H} 1 \mathrm{~N} 1$ swine influenza, which originated in Mexico, quickly spiraled into a pandemic that made hundreds of thousands of people sick worldwide.

Finally, we include two variables measuring outbreaks of Ebola, Ebola and Ebola 2014. Ebola is a lethal form of viral hemorrhagic fever that infects both humans and primates. While the first outbreak occurred in 1976, Ebola caused a string of outbreaks across Africa in the 1990s and 2000s. The variable Ebola captures the case counts associated with these intermittent outbreaks from 1995 through the third quarter of 2020 excluding the 2014 Ebola epidemic. These outbreaks collectively resulted in more than 5,000 human cases. We treat the Ebola 2014 epidemic as a separate event because it resulted in nearly six times the number of cases as the previous outbreaks, including a few cases in the U.S. and Europe.

\section{Analysis}

\section{COVID-19 and Agenda Change}

We begin our analysis by estimating a baseline model to capture the agenda effect of all the emerging diseases described above - except for COVID-19 - on the media and congressional agenda. We created a variable combining the number of cases associated with SARS, avian influenza, swine influenza, the 2014 Ebola epidemic, and the various Ebola outbreaks of the 1990s and 2000s. To ease interpretation, we transformed this variable to a z-score. Our baseline model indicates that every one-standard deviation increase in the number of emergingdisease cases (roughly 39,513 cases) results in an approximate $26 \%$ increase in the number of Congressional Record entries and a $48 \%$ increase in the number of stories published in the New York Times. 
Table 2: Agenda Change and Novel Diseases

\begin{tabular}{|c|c|c|}
\hline Independent Variables & $\begin{array}{l}\text { Model } 1 \\
\text { Congressional Record }\end{array}$ & $\begin{array}{l}\text { Model } 2 \\
\text { New York Times }\end{array}$ \\
\hline COVID-19 & $.706(.1595)^{* * *}$ & $3.394(.7428)^{* * *}$ \\
\hline SARS & $.160(.0937)^{*}$ & $.317(.1440)^{* *}$ \\
\hline Ebola 2014 & $.119(.0924)$ & $.394(.1704)^{* *}$ \\
\hline Ebola & $.052(.0934)$ & $.004(.1338)$ \\
\hline Avian Influenza & $.318(.1175)^{* * *}$ & $.146(.1687)$ \\
\hline Swine Influenza & $.145(.1073)$ & $.281(.1792)$ \\
\hline Intercept & $3.238(.0991)^{* * *}$ & $4.003(.1424)^{* * *}$ \\
\hline $\mathrm{N}$ & 103 & 103 \\
\hline Mean & 40.30 & 183.1068 \\
\hline Deviance goodness of fit (value/df) & 1.233 & 1.328 \\
\hline Log likelihood & -438.652 & -494.876 \\
\hline Chi-square likelihood ratio & 70.946 & 475.709 \\
\hline
\end{tabular}

Note: Estimated coefficients are z-scores. Standard errors in parentheses ${ }^{*} \mathrm{p}<0.10,{ }^{* *} \mathrm{p}<0.05,{ }^{* * *} \mathrm{p}<0.01$; two-sided test of significance

\section{Source: The Authors}

Given the baseline model characteristics, Table 2 adds COVID-19 and treats avian influenza, swine influenza, SARS, Ebola 2014, and Ebola as discrete events. Deviance goodness-of-fit tests are used to assess how well observed data fit the model. Scores closer to " 1 " indicate a better model fit. Deviance goodness-of-fit testing for both the Congressional Record (goodnessof-fit=1.233), as well as the New York Times models (goodness-of-fit=1.328), suggest a strong fit. Moreover, chi-square likelihood ratios for the Congressional Record model (chi-square likelihood ratio $=70.946$ ) and the New York Times model (chi-square likelihood ratio=475.709) indicate that our models are a significant improvement over the null. 
We once again transform independent variables to z-scores to help ease the interpretation of the models. Model 1 indicates that COVID-19 had a dramatic and statistically significant effect on the Congressional Record. Specifically, every one-standard deviation increase in COVID-19 cases (roughly 1,729,032 cases) resulted in an almost 70\% increase in Congressional Record entries. In comparison, a one-standard deviation increase in SARS cases (roughly 685 cases) and avian influenza cases (roughly 8 cases), the only other statistically significant predictors in Model 1, resulted in $16 \%$ and $32 \%$ increases in Congressional Record entries, respectively.

Model 2 indicates that novel-disease outbreaks have an even greater effect on the media agenda; however, COVID-19 stands out. Every one-standard deviation increase in the number of COVID-19 cases results in a more than 300\% increase in New York Times stories. The other statistically significant predictors in our model, the 2014 Ebola epidemic and SARS, generated modest upticks in attention but ultimately paled in comparison to COVID-19. Specifically, a one-standard deviation increase in Ebola 2014 cases (roughly 1,526 cases) results in a 39\% increase in New York Times stories, whereas a one-standard deviation increase in SARS cases results in a $32 \%$ increase in media attention.

Of course, these results should be interpreted with caution because the estimates are based on nine months of COVID-19 data. It is plausible that issue attention will wane in the months ahead, especially if the number of cases drops. However, the sheer magnitude of COVID-19's impact on the government and media suggests that the pandemic will continue to have a profound effect on issue attention, especially when compared with previous outbreaks. These results are especially striking because previous research suggests that avian influenza and Ebola triggered fairly robust policy change at the congressional level and were widely considered watershed events in the public health domain (DeLeo, 2018).

\section{COVID-19 Through the Lens of Focusing Event Theory}

The following section assesses the extent to which the characteristics of the current COVID-19 crisis match Birkland's (1997) definition of a focusing event as being: (1) sudden and relatively rare; (2) harmful or revealing possible future harms; (3) confined to a geographical area; and (4) known to policymakers and the public simultaneously. Table 3 suggests that COVID-19 is different from the classic conceptualization of focusing events. First, although COVID-19 is undoubtedly a serious event, it cannot be characterized as sudden, at least from the perspective of U.S. policymakers. The disease was first identified in Wuhan, China, in December 2019 and it was not until late January 2020 that the WHO classified the outbreak as a Public Health Emergency. On January 20, 2020, nearly a month after the disease was identified in China, the U.S. reported its first case of COVID-19 (Holshue et al. 2020). The first known instances of community spread in the U.S. occurred in late February 2020 (CDC COVID-19 Response Team et al., 2020). Although the COVID-19 pandemic escalated quickly, the event was neither relatively sudden nor unexpected in the way that a hurricane is (providing only a few days of lead time for preparation), or an earthquake or plane crash, which happen with no warning. 
Table 3: Focusing Events and COVID-19

\begin{tabular}{|l|l|l|}
\hline Focusing Events & COVID-19 & Features of COVID-19 \\
\hline Sudden, relatively rare & Yes/No & Relatively rare, but not sudden \\
\hline Harmful and reveals future harms & Yes & Harmful and revealed future harms \\
\hline Concentrated geographic area & No & Global in scope \\
\hline $\begin{array}{l}\text { Known to policymakers and public } \\
\text { simultaneously }\end{array}$ & No & $\begin{array}{l}\text { Policymakers were aware before } \\
\text { public }\end{array}$ \\
\hline
\end{tabular}

Source: The Authors

Second, the virus is not concentrated in a specific geographical area. By definition, a pandemic is "an epidemic occurring worldwide, or over a very wide area, crossing international boundaries and usually affecting a large number of people" (Kelly, 2011, p. 540). COVID-19 has caused widespread illness and has stifled the global economy, making it a far different type of disaster than the natural and man-made incidents examined in the focusing events literature. It is a global pandemic, although the harms are distributed unevenly across different geographical regions of the world and the U.S. Indeed, uneven effects are being observed within the U.S. The effects of the novel coronavirus are particularly severe for members of vulnerable populations, specifically Black American, Hispanics, Native Americans, and the elderly (Kaiser Family Foundation, 2020).

Third, COVID-19 was not known to policymakers and the public simultaneously. Chinese public health officials reported the outbreak of a cluster of respiratory infections on December 31, 2019. Less than a week later, the cluster was confirmed as being caused by a novel coronavirus (Patel \& Jernigan, 2020). Media reports indicating the outbreak of a virus in China causing flu-like symptoms did not appear in the New York Times until January 6, 2020 (Wee \& Wang, 2020). On January 4, 2020, the Food and Drug Administration issued emergency protocols for testing and on January 7, 2020 the CDC activated its Incident Management Structure to guide its response (Patel \& Jernigan, 2020). This indicates that public health officials were aware of the virus at least a week before the general public was. Widespread media coverage of the virus did not begin until February and March, which means that most Americans were likely to have been unconcerned with the virus until that point. Finally, recent reporting suggests that President Donald Trump knew about the seriousness of the pandemic relatively early in the U.S outbreak, but played down the severity of the virus, further underscoring information asymmetries between elites and the general public (Goldberg, 2020; Gregorian, 2020).

The single aspect of the crisis that dovetails with Birkland's definition of a focusing event is the way in which it reveals harms. COVID-19 revealed the risk of infection and, as the pandemic endures, it continues to reveal additional harms. Indeed, as noted throughout, COVID-19 represents one of the greatest public health crises in modern history. 


\section{COVID-19 and Policy Change}

COVID-19 bowled over the media and policy agendas in early 2020 and shares some similarities and differences with the classic definition of a focusing event. But has this attention translated into policy change? Table 4 summarizes the eleven items of legislation related to COVID-19 enacted by the U.S. Congress from the start of the pandemic in March 2020 to the third quarter of 2020. The pandemic has clearly opened a policy window. From a $\$ 2$ trillion-dollar economic relief program to an $\$ 8.3$ billion public health response initiative, Congress enacted a series of sweeping policies in response to the crisis. This response spanned multiple policy domains in addition to public health, including the economy, education, social welfare, and law enforcement. May and Jochim coined the term "policy regimes" to describe this boundary-spanning nature of disasters, in which there is "the constellation of ideas, institutional arrangements, and interests that are involved in addressing policy problems" (2013, p. 426). COVID-19 appears to fit the mold of a boundary-spanning issue. It is, therefore, unsurprising that policy change in Congress has spanned multiple jurisdictional and issue areas.

Table 4: Federal Legislation Enacted in Response to COVID-19

\begin{tabular}{|c|c|c|c|c|c|}
\hline $\begin{array}{l}\text { Public } \\
\text { Law } \\
\text { No: }\end{array}$ & Title & Summary & $\begin{array}{l}\text { Chamber: } \\
\text { Committees }\end{array}$ & Introduced & $\begin{array}{l}\text { Became } \\
\text { Law }\end{array}$ \\
\hline $116-123$ & $\begin{array}{l}\text { Coronavirus } \\
\text { Preparedness and } \\
\text { Response } \\
\text { Supplemental } \\
\text { Appropriations Act, } \\
2020\end{array}$ & $\begin{array}{l}\text { Provides } \$ 8.3 \text { billion } \\
\text { in emergency for } \\
\text { federal agencies } \\
\text { responding to } \\
\text { COVID-19 } \\
\text { pandemic, including } \\
\text { Department of Health } \\
\text { and Human Services, } \\
\text { Department of State, } \\
\text { and Small Business } \\
\text { Administration. }\end{array}$ & $\begin{array}{l}\text { House: Budget: } \\
\text { Appropriations }\end{array}$ & 03/04/2020 & 03/06/2020 \\
\hline $116-127$ & $\begin{array}{l}\text { Families First } \\
\text { Coronavirus } \\
\text { Response Act }\end{array}$ & $\begin{array}{l}\text { Responds to } \\
\text { coronavirus } \\
\text { pandemic by } \\
\text { providing paid sick leave, } \\
\text { tax credits, and free } \\
\text { cOVID-19 testing; ex- } \\
\text { panding food assistance } \\
\text { and unemployment } \\
\text { benefits; and increasing } \\
\text { Medicaid funding. }\end{array}$ & $\begin{array}{l} \\
\text { House: Ways } \\
\text { and Means: } \\
\text { Budget: } \\
\text { Appropriations }\end{array}$ & 03/11/2020 & 03/18/2020 \\
\hline
\end{tabular}




\begin{tabular}{|c|c|c|c|c|c|}
\hline $116-128$ & $\begin{array}{l}\text { A bill to authorize } \\
\text { the Secretary of } \\
\text { Veterans Affairs to } \\
\text { treat certain } \\
\text { programs of } \\
\text { education converted } \\
\text { to distance learning } \\
\text { by reason of } \\
\text { emergencies and } \\
\text { health-related } \\
\text { situations in the } \\
\text { same manner as } \\
\text { programs of } \\
\text { education pursued } \\
\text { at educational } \\
\text { institutions, and for } \\
\text { other purposes. }\end{array}$ & $\begin{array}{l}\text { Authorizes Veterans } \\
\text { Administration to } \\
\text { continue providing } \\
\text { educational assistance } \\
\text { during the COVID-19 } \\
\text { pandemic. }\end{array}$ & Senate & 03/16/2020 & 03/21/2020 \\
\hline $116-136$ & CARES Act & $\begin{array}{l}\text { Authorizes } \$ 2 \text { trillion } \\
\text { to address COVID-19 } \\
\text { and its economic } \\
\text { fallout, including cash } \\
\text { relief to individual } \\
\text { citizens, loan } \\
\text { programs for small } \\
\text { businesses, support } \\
\text { for hospitals, as well } \\
\text { as various other } \\
\text { programs to support } \\
\text { impacted industries. }\end{array}$ & $\begin{array}{l}\text { House: Ways } \\
\text { and Means }\end{array}$ & $01 / 24 / 2019^{1}$ & 03/27/2020 \\
\hline $116-140$ & $\begin{array}{l}\text { Paycheck Protection } \\
\text { Program and Health } \\
\text { Care Enhancement } \\
\text { Act }\end{array}$ & $\begin{array}{l}\text { Provides additional } \\
\text { funding for small } \\
\text { business loans, health } \\
\text { care providers, and } \\
\text { COVID-19 testing. }\end{array}$ & $\begin{array}{l}\text { House: } \\
\text { Appropriations }\end{array}$ & 01/08/2019 & $04 / 24 / 2020$ \\
\hline 116-142 & $\begin{array}{l}\text { Paycheck Protection } \\
\text { Program Flexibility } \\
\text { Act of } 2020\end{array}$ & $\begin{array}{l}\text { Modifies provisions } \\
\text { related to the } \\
\text { forgiveness of loans } \\
\text { made to small } \\
\text { businesses under the } \\
\text { Paycheck Protection } \\
\text { Program }\end{array}$ & $\begin{array}{l}\text { House: Ways } \\
\text { and Means: } \\
\text { Small Business }\end{array}$ & 05/26/2020 & $06 / 05 / 2020$ \\
\hline
\end{tabular}

1 - In both of these bills, the Senate used an unrelated bill that had already passed the House in 2019, amended it and sent it back to the House to final approval in order to expedite passage of the legislation. 


\begin{tabular}{|c|c|c|c|c|c|}
\hline $116-147$ & $\begin{array}{l}\text { A bill to extend the } \\
\text { authority for } \\
\text { commitments for } \\
\text { the paycheck } \\
\text { protection program } \\
\text { and separate } \\
\text { amounts authorized } \\
\text { for other loans } \\
\text { under section 7(a) } \\
\text { of the Small } \\
\text { Business Act, and } \\
\text { for other purposes. }\end{array}$ & $\begin{array}{l}\text { Extends the application } \\
\text { period for the Paycheck } \\
\text { Protection Program } \\
\text { established to support } \\
\text { small businesses in } \\
\text { response to COVID-19. }\end{array}$ & Senate & 06/30/2020 & 07/04/2020 \\
\hline $116-148$ & $\begin{array}{l}\text { Emergency Aid for } \\
\text { Returning Ameri- } \\
\text { cans Affected by } \\
\text { Coronavirus Act }\end{array}$ & $\begin{array}{l}\text { Increases funding } \\
\text { and requirements for, } \\
\text { temporary assistance for } \\
\text { U.S. citizens and their } \\
\text { dependents who are } \\
\text { returning from foreign } \\
\text { countries due to a crisis } \\
\text { and are without available } \\
\text { resources. }\end{array}$ & Senate & 06/29/2020 & 07/13/2020 \\
\hline $116-151$ & $\begin{array}{l}\text { Protecting Nonprof- } \\
\text { its from } \\
\text { Catastrophic Cash } \\
\text { Flow Strain Act of } \\
2020\end{array}$ & $\begin{array}{l}\text { Permits certain } \\
\text { governmental entities, } \\
\text { federally recognized } \\
\text { tribes, and nonprofit } \\
\text { organizations to make up } \\
\text { front payments of } 50 \% \text {, } \\
\text { as opposed to } 100 \% \text {, of } \\
\text { unemployment benefits } \\
\text { into the state } \\
\text { Unemployment Trust } \\
\text { Fund (in lieu of } \\
\text { contributions) to be used } \\
\text { exclusively to reduce such } \\
\text { payments resulting from } \\
\text { the COVID-19. }\end{array}$ & Senate & 07/02/2020 & 08/03/2020 \\
\hline $116-157$ & $\begin{array}{l}\text { Safeguarding } \\
\text { America's First } \\
\text { Responders Act of } \\
2020\end{array}$ & $\begin{array}{l}\text { Extends death and dis- } \\
\text { ability benefits under the } \\
\text { Public Safety Officers' } \\
\text { Benefits Program (PSOB) } \\
\text { to public safety officers } \\
\text { (e.g., law enforcement } \\
\text { officers) and survivors of } \\
\text { public safety officers who } \\
\text { die or become injured as } \\
\text { a result of COVID-19 }\end{array}$ & $\begin{array}{l}\text { Senate: } \\
\text { Judiciary }\end{array}$ & $05 / 05 / 2020$ & 08/14/2020 \\
\hline
\end{tabular}




\begin{tabular}{|l|l|l|l|l|l|}
\hline A bill to amend the \\
$\begin{array}{l}\text { Servicemembers } \\
\text { Civil Relief Act }\end{array}$ & $\begin{array}{l}\text { Extends lease } \\
\text { protections for } \\
\text { servicemembers under } \\
\text { stop movement orders } \\
\text { in response to a local, } \\
\text { national, or global } \\
\text { emergency, and for other } \\
\text { purposes. }\end{array}$ & $\begin{array}{l}\text { Senate: } \\
\text { Veteran's Affairs }\end{array}$ & $05 / 06 / 2020$ & $08 / 14 / 2020$ \\
\hline
\end{tabular}

Source: The Authors

Despite these important pieces of legislation, closer analysis suggests that the COVID-19 pandemic has yet to result in the type of informed lesson learning needed to truly reconfigure subsystem dynamics and create policy change. The legislation enacted and detailed in Table 4 was intended to mitigate the effects of the pandemic on public health, the economy, and education in near real time. All the bills enacted focus on economic stimulus, on new programs to aid in coronavirus testing or care, and on providing additional COVID-19-related flexibility to programs that already exist, which typically have strict guidelines governing spending or program limits. One exception to this pattern is the Paycheck Protection Program (PPP) modifications made during June and July 2020 (PL 116-142). Once enacted into law in March 2020, Congress received a significant volume of feedback from constituent small businesses about the effectiveness of the PPP, its implementation, and the rule that limited the overall loan amount that small businesses could direct towards overheads versus staff salary in order to qualify for loan forgiveness. Based on this feedback, the Small Business Committee in the U.S. House modified requirements to provide the needed flexibility (PL 116-147).

This type of legislative response can be described as instrumental learning, or lesson drawing, where policy instruments are modified in response to new information (May, 1992; Birkland, 2004). As previously noted, the COVID-19 legislation passed by the U.S. Congress does not seek to amend or alter existing policies and institutions in order to prevent a similar crisis from happening again in the future. The ways in which Congress has adapted to conduct business remotely (Grisales, 2020) are evidence of government learning, in which government learns how to improve procedures and processes (Howlett, 2012; McConnell, 2010b). These recommendations were made after $9 / 11$ by the Continuity of Government Commission and are routinely brought up by proponents of congressional reform (Ornstein 2020), so the accumulation of knowledge from multiple experiences may also be important to the changes made during COVID-19.

In addition to the ongoing nature of the crisis, there are a number of ways that it has affected the institution of Congress itself, which may prevent or delay government, organizational, or social learning. This sort of learning would be necessary for major policy change that would result in restructuring or re-envisioning government agencies, programs, and goals to prevent future similar crises. Like most Americans, Members of Congress worked remotely from home between March and June 2020. Normally, congressional business would require near-weekly trips to Washington, D.C. to vote and to hold hearings. In this three-month timespan, there were three series of votes that focused entirely on COVID-19 legislation. All other legislative business was moved off the calendar and delayed until late 2020. In late June, mid-July, and September, Congress returned for modified shortened vote weeks, which focused primarily on must-pass legislation such as the federal budget. 
In May 2020, the House of Representatives voted to allow a number of rule changes so that the chamber could continue its work despite the COVID-19 crisis. Remote hearings were allowed, along with a modified proxy-voting process (Grisales, 2020). This meant that most business during the entirety of 2020 was done in a modified format. Hearings were conducted partially via remote technology, congressional office buildings were mostly vacant as staff worked remotely, caucus meetings and other formal and informal meetings were cancelled or took place remotely, and votes were held in small groups alphabetically instead of as a full chamber (Tully-McManus, 2020). This last change delayed the business of Congress because votes took much longer (being conducted over hours, rather than in 5- or 15-minute segments, as small groups of Representatives came to the chamber briefly to cast their votes). Together, these rule changes meant that the networking and relationship-building that takes place through both formal and informal means among Members of Congress was more difficult during 2020. These avenues are one important mechanism through which the uptake of new information, exchange of ideas, and learning can take place. While still to be determined, these changes may influence the speed and ability of Congress to learn from the COVID-19 crisis.

Because COVID-19 remains a vexing public health crisis, Congress has yet to engage in the type of sustained lesson-learning necessary for major policy change. COVID-19 bowled over the entire agenda, in spite of competition for attention during the pandemic from other issues such as race relations and police power, natural disasters, and the nomination of a U.S. Supreme Court justice. The dominance of COVID-19 on the policy agenda speaks to the severity of the problem and to the focal power of the event over its duration.

\section{During the Disaster: Refining the Concept of Focusing Events}

The COVID-19 pandemic raises a number of important theoretical challenges to policy process theory and, in particular, to research on focusing events. On the one hand, it lacks many of the characteristics used to describe focusing events. It was neither sudden nor unexpected. It is not isolated to a specific geographical area, but is global in scope. Nor has it been isolated within a community of interest. Moreover, it appears that policymakers in the U.S. were well aware of the virus - and its lethality - weeks, if not months, before the general public. On the other hand, it reshaped the congressional and media agendas in much the same way as a focusing event, dominating issue attention since March 2020. And although Congress has yet to pass the sort of sweeping reforms needed to avert another pandemic in the future, this pandemic has resulted in a windfall of legislation and spending to help to mitigate the devastating effects of the virus on public health and the economy.

The challenge of characterizing COVID-19 stems from the fact that indicators and focusing events are said to align along a dichotomy, with indicators measuring gradually deteriorating issues and focusing events measuring sudden events. But this research, set in the context of previous work on focusing events and problem indicators, suggests that these two drivers of agenda change may fall more on a continuum. Echoing previous research (DeLeo, 2018), we argue that, when indicators accumulate rapidly, they can have a catalytic effect on media and policymaker attention paid to previously ignored issues. Moreover, studies of aggregate focusing events suggest that an accumulation of several focusing events over time leads to policy change (O'Donovan, 2017). When viewed as a whole, the duration of the effects of a policy problem, whether in more durable indicators or in repeated focusing events, seems to be an important theme in the literature, magnified by the policy implications of the COVID-19 pandemic. 
We propose a two-by-two typology for organizing scholarly thinking about indicators, events, and their effect on the trajectory of agenda setting, policy change, and learning (Figure 1). The $\mathrm{x}$-axis of Figure 1 describes the rate of indicator accumulation or the speed at which cases or other indicators of a problem amass and multiply. Consistent with previous research (Birkland 2006; DeLeo, 2018), we assume that the rate of accumulation can vary from gradual, which refers to situations where there is small to modest change in the number of indicators over a prolonged period of time (several more months or even years), to rapid accumulation, which refers to sizable changes in the number of indicators over a short period of time (weeks to a few months). We also add a dimension accounting for the duration of the effects of an event, depicted on the $y$-axis of Figure 1. Here we differentiate between short-duration events, referring to events that only last for a few weeks to a couple of months, to long-duration events, which refer to events that linger for several months to more than a year.

Policy process theory emphasizes that all problems, including disasters, are to some extent socially constructed, so variation in the rate of accumulation and duration of an event will likely be somewhat contextual (Birkland, 2006; Kingdon, 2003). The public health domain's differentiation between disease outbreaks, epidemics, and pandemics provides a useful analog. An outbreak is a greater than expected number of disease cases. An epidemic refers to a larger outbreak typically confined to a particular geographical area. A pandemic refers to a global disease outbreak. There is no definitive threshold used to determine whether a disease event constitutes an outbreak, an epidemic, or a pandemic. Rather, these categories reflect the size and scope of the disease event and a disease's novelty, which helps to determine whether an event deviates from our expectations of normal transmission within a community.

Figure 1: The Indicator-Event Continuum

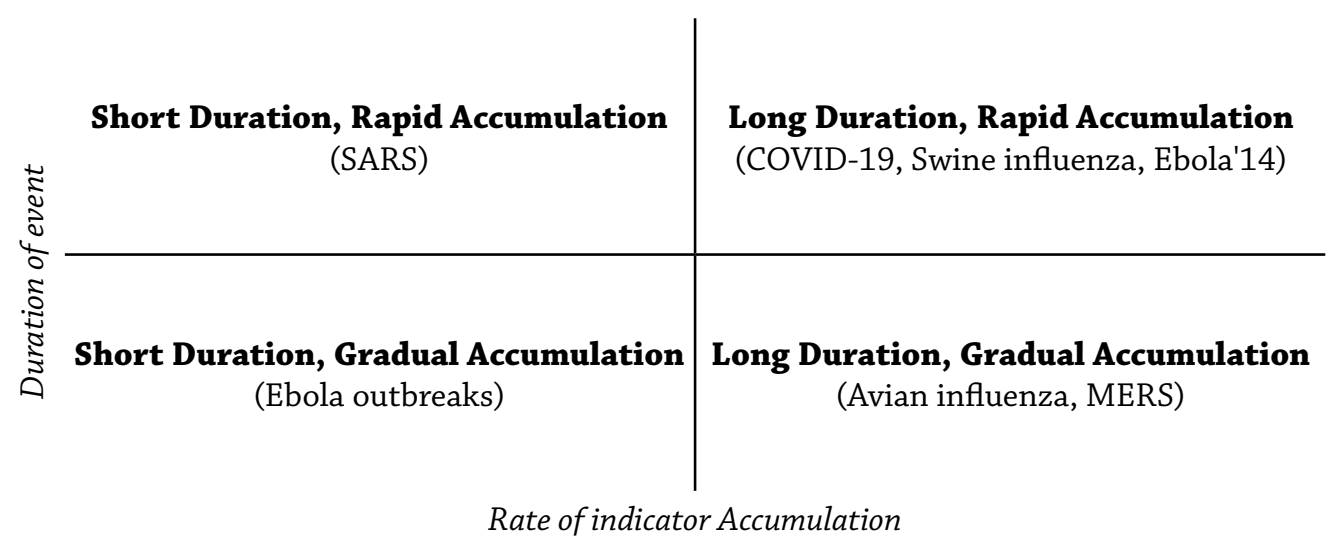

Source: The Authors

We are presented with four distinct contexts for assessing the effect of indicators and focusing events on agenda setting, policy change, and lesson learning. Short-duration, gradual-accumulation events (lower left panel) typically describe novel disease outbreaks that fail to capture policymaker attention, such as the various Ebola outbreaks of the 1990s and 2000s. Indicators suggested a potential problem, but they rarely meet the critical mass needed to trigger widespread concern, at least among U.S. policymakers. These events are typically confined to a very specific geographical area and are therefore less likely to drive agenda setting, let alone the type of informed lesson learning needed to trigger substantive policy change. 
Long-duration, gradual-accumulation events (lower right panel) also see a gradual and modest accumulation of indicators; however, in this instance, the event lingers for an extended period. The avian influenza outbreak, for example, lasted for several years, but, because the virus never mutated into an airborne strain, it failed to trigger a global pandemic. This pattern lends itself to the indicator-driven policy process described by Birkland (2006) and others (DeLeo, 2018; DeLeo, 2021). Because cases accumulate slowly, policymakers are presented with an opportunity to develop preparedness or pre-event policymaking, a testament to the fact that indicators point to the possibility of a larger problem on the horizon (DeLeo, 2018; DeLeo, 2021). Previous research implies that these conditions can lead instrumental policy learning as most pre-event policy changes seek to prepare for the emerging hazard rather than make systemic changes to avoid such risks. For example, the specter of an avian influenza pandemic caused policymakers to revisit organizational structures used to manage public health emergencies, as well as key liability laws governing vaccine creation and distribution (DeLeo, 2018).

Short-duration, rapid-accumulation events (upper left panel) are marked by a sudden, but relatively short-lived, spike in indicators. This is the typical focusing event pattern observed in most natural disasters or terrorist events studied in the disaster policy literature. It is also found in numerous public health cases, such as the 2003 SARS outbreak where a sharp uptick in cases occurred between November and March; however, this incident had been mostly contained by early spring. Although we did not assess whether SARS facilitated policy change, our quantitative analysis shows that SARS had a considerable impact on both the media and congressional agendas as it was the only statistically significant variable in both models aside from COVID-19. We would not, however, expect to see considerable policy learning in these instances since they rapidly fade from the institutional agenda. The policy changes that take place in these cases are more likely to fall in the instrumental, or even mimicking, categories.

Finally, and most important for this study, rapid-accumulation, long-duration events (upper right panel) are marked by a rapid and significant accumulation of indicators that create a persistent crisis situation extending over a period of months to years, such as COVID-19. As COVID-19 cases accumulate, we move from an issue-attention process driven by indicators to one driven by something that is conceptualized by policymakers and the public as a singular event. In the context of COVID-19, public attention does not appear to scrutinize individual cases or case counts as they mount in one state and then another. Instead, milestones seem to garner more attention - 100,000 cases, 1,000,000 cases, 100,000 deaths and so on. Not only do these types of events bowl their way onto the policy agenda, but the COVID-19 pandemic suggests that they also facilitate multiple windows of opportunity. Because these events linger for an extended period of time, they often require the enactment of policies that alleviate suffering and support the various government institutions responding to the crisis. In many respects, this type of policy is akin to disaster relief projects that funnel resources into hazardstricken areas.

While these types of activities during disaster are no doubt important, they differ from the type of informed lesson learning that can occur in the aftermath of other types of disasters. Others have observed a similar phenomenon during the swine influenza pandemic, noting that, while Congress devoted a considerable amount of time to discussing and debating the Obama Administration's response to the crisis, most of the policy enacted during this period centered on funding vaccine production and on other vaccines (DeLeo, 2015). Still, our modelling suggests that COVID-19 is unlike any public crisis in decades, so it is likely that, once the pandemic recedes, Congress will reform the nation's public health infrastructure. These changes could 
result in increasing investments in public health preparedness, strengthening the response capabilities of states, re-envisioning the Center for Disease Control and Prevention's role in collecting and disseminating public health information, or other substantive reforms equivalent to the institutional and policy changes enacted after the September 11, 2001 terror attacks.

Of course, where an issue sits on our typology can change over time. Indicator change is dynamic so an event - and especially a disease outbreak — can quickly transition from several years of gradual accumulation to rapid accumulation at a moment's notice. This means that our typology encompasses policymaking before, during and after a disaster, although our focus here is on policymaking during the COVID-19 pandemic. Finally, it is important to note that neither indicator accumulation nor the duration of an event are sufficient catalysts for policy change. Our typology is intended to help to organize thinking about the context of agenda setting, policy change, and learning; however, whether or not policymakers choose to act on an issue is ultimately a political question. Disasters - be they tornadoes, earthquakes, or disease outbreaks - have the potential to trigger issue attention and agenda setting, but change is never guaranteed (Birkland, 1997).

\section{Conclusion}

Our study represents a first attempt to assess systematically the policymaking implications of the COVID-19 pandemic through the lens of focusing event theory. The COVID-19 pandemic represents a fluid and evolving situation. We are, as the title suggests, analyzing policymaking during disaster. As such, key findings, particularly with respect to the scope of policy learning, need to be revisited in the months and years ahead as testament to the inherent challenges associated with doing policy process research in near real time (Weible et al., 2020).

Our typology necessitates closer analysis since our primary focus in this paper is on rapid-accumulation, long-duration events. Future research should continue to sharpen and refine our definitions of duration and rate of accumulation while applying our typology outside the U.S. For example, to what extent does proximity to a problem dictate the relative influence of indicator change? China's experience of managing COVID-19, as well as H5N1 avian influenza, is likely to be far different from that of the U.S. since both diseases originated within its borders.

Above all else, our study of COVID-19 shows that the timing and duration of a crisis matter (DeLeo, 2015). This finding is important for two reasons. First, we show that enduring crises can open multiple windows of opportunity to address different, boundary-spanning policy problems revealed by the event over time. Future research should consider the extent to which this dynamic occurs in others hazards, including the governance of climate change and perhaps other novel disease outbreaks.

Second, our findings help to shift the theoretical understanding and empirical investigation of focusing events to account for longer-duration events, such as pandemics, droughts, sea-level rise, or economic recessions, to allow for the aggregation of events and for potential learning along the way that can occur as a result. More specifically, our typology suggests the need to move away from framing indicators (or information) and focusing events (or exogenous shocks) as discrete concepts. Instead, we suggest that they align along a continuum in that emergent hazards can, across time, evolve into large-scale crises that embody many of the key characteristics ascribed to focusing events. This finding suggests that scholars across the policy sciences should consider the time during a disaster as an important factor for policy change, especially within the context of slower-onset, longer-duration events. 


\section{Bibliography}

't Hart, P., \& Tindall, K. (2009). Leadership by the famous: Celebrity as political capital. In J. Kane, H. Patapan \& P. 't Hart (Eds.), Dispersed Democratic Leadership: Origins, Dynamics, and Implications (pp. 255-278). Oxford: Oxford University Press.

Albright, E. A. (2011). Policy change and learning in response to extreme flood events in Hungary: An advocacy coalition approach. Policy studies journal, 39(3), 485-511.

Albright, E.A. \& Crow, D.A. (2021). Capacity Building Toward Resilience: How Communities Recover, Learn, and Change in the Aftermath of Extreme Events. Policy Studies Journal, 49(1) 89-121.

Baumgartner, F.R., \& B. D. Jones. (2009). Agendas and Instability in American Politics. 2nd ed. Chicago, IL: University of Chicago Press.

Béland, D., Marchildon, G.P., Medrano, A., \& Rocco, P. (2021). COVID-19, Federalism, and Health Care Financing in Canada, the United States, and Mexico. Journal of Comparative Policy Analysis: Research and Practice.

Béland, D., \& Marier, P. (2020). COVID-19 and Long-Term Care Policy for Older People in Canada. Journal of Aging \& Social Policy, 32(4-5), 358-364.

Birkland, T. A. (1997). After Disaster: Agenda Setting, Public Policy and Focusing Events. Washington, DC: Georgetown University Press.

Birkland, T. A. (1998). Focusing events, mobilization, and agenda setting. Journal of Public Policy, 18(1), 53-74.

Birkland, T. A. (2004). Learning and policy improvement after disaster: The case of aviation security. American Behavioral Scientist, 48(3), 341-364.

https://doi.org/10.1177/0002764204268990

Birkland, T. A. (2006). Lessons of disaster: Policy change after catastrophic events. Washington, DC: Georgetown University Press.

Burgess, J.T. (2020). Is Sustainability Possible During COVID? Rewire. Sept. 23.

CDC COVID-19 Response Team, Jorden, M. A., Rudman, S. L., Villarino, E., Hoferka, S., Patel, M. T., Bemis, K., Simmons, C. R., Jespersen, M., Iberg Johnson, J., Mytty, E., Arends, K. D., Henderson, J. J., Mathes, R. W., Weng, C. X., Duchin, J., Lenahan, J., Close, N., Bedford, T., ... Chung, J. R. (2020). Evidence for limited early spread of COVID-19 within the United States, January-February 2020. MMWR. Morbidity and Mortality Weekly Report, 69(22), 680-684.

https://doi.org/10.15585/mmwr.mm6922e1

Crow, D.A., Lawhon, L., Berggren, J., Huda, J., Koebele, E., Kroepsch, A. (2017). A Narrative Policy Framework Analysis of Wildfire Policy Responses. Politics \& Policy, 45(4), 626-656.

Crow, D.A., \& Albright, E.A. (2019). Intergovernmental Relationships after Disaster: State and Local Government Learning during Flood Recovery in Colorado. Journal of Environmental Policy \& Planning, 21(3), 257-274.

Crow, D.A., Berggren, J., Lawhon, L., Koebele, E., Kroepsch, A, \& Huda, J. (2016). Local Media Coverage of Wildfire Disasters: An Analysis of Problems and Solutions in Policy Narratives. Environment and Planning C: Government and Policy, 35(5), 849-871. 
DeLeo, R.A. (2015). Anticipatory policymaking: when government acts to prevent problems and why it is so difficult. New York: Routledge.

DeLeo, R.A. (2018). Indicators, agendas and streams: analysing the politics of preparedness. Policy \& Politics, 46, 27-45.

DeLeo, R.A. (2021). Does data drive policymaking? A multiple streams perspective on the relationship between indicators and agenda setting. Policy Studies Journal, Early view online.

Delshad, A. (2012). Revisiting 'who influences whom?' Agenda setting on biofuels. Congress and the Presidency, 39, 177-198.

DeYoung, S. E., \& Penta, S. (2017). Issue attention and group mobilization for caste rights following the 2015 Gorkha, Nepal, Earthquake. Earthquake Spectra, 33(1, SI), S403+.

https://doi.org/10.1193/120716EQS225M

Downs, A. (1972). Up and down with ecology: The issue attention cycle. The Public Interest, 28 (Summer), 38-50.

Freed, M., Cubanski, J., Neuman, T, Kates, J. \& Michaud, J. (2020, July 24). What Share of People Who Died of COVID-19 Are 65 and Older-And How Does It Vary By State? Kaiser Family Foundation. Retrieved from: https://www.kff.org/coronavirus-covid-19/issue-brief/what-share-of-people-who-have-died-ofcovid-19-are-65-and-older-and-how-does-it-vary-by-state/

Goldberg, M. (2020, September 10). Trump's deliberate coronavirus deception. The New York Times. Retrieved from: https://www.nytimes.com/2020/09/10/opinion/sunday/trump-woodward-coronavirus-tapes.html.

Gregorian, D. (2020). Trump told Bob Woodward he knew in February that COVID-19 was 'deadly stuff' but wanted to 'play it down.' NBC News. Retrieved from:

https://www.nbcnews.com/politics/donald-trump/trump-told-bob-woodward-he-knew-februarycovid-19-was-n1239658.

Grisales, C. (2020, May 15). With historic vote, House will allow proxy voting, remote hearings during pandemic. NPR. Retrieved from:

https://www.npr.org/sections/coronavirus-live-updates/2020/05/15/856403393/with-historicvote-house-will-allow-proxy-voting-remote-hearings-during-pandemic

Heikkila, T., \& Gerlak, A. K. (2013). Building a conceptual approach to collective learning: Lessons for public policy scholars. Policy Studies Journal, 41(3), 484-512.

Herweg, N., Zahariadis, N., \& Zohlnhöfer, R. (2017). The Multiple Streams Framework: Foundations, refinements, and empirical applications. In C.M. Weible \& P.A. Sabatier (Eds.), Theories of the Policy Process (4th ed.) (pp. 17-53). . Boulder, CO: Westview Press.

Hoffman, J.A., \& Edward, A. Miller, E.A. (2020). Addressing the Consequences of School Closure Due to COVID-19 on Children's Physical and Mental Well-Being. World Medical \& Health Policy, 12(3),300-310.

Holshue, M. L., DeBolt, C., Lindquist, S., Lofy, K. H., Wiesman, J., Bruce, H., Spitters, C., Ericson, K., Wilkerson, S., Tural, A., Diaz, G., Cohn, A., Fox, L., Patel, A., Gerber, S. I., Kim, L., Tong, S., Lu, X., Lindstrom, S., ... Pillai, S. K. (2020). First Case of 2019 Novel Coronavirus in the United States. New England Journal of Medicine, 382(10), 929-936.

https://doi.org/10.1056/NEJMoa2001191.

Howlett, M. (2012). The lessons of failure: learning and blame avoidance in public policy-making. International Political Science Review, 33(5), 539-555. 
Hur, J.Y., \& Kim. K. (2020). Crisis Learning and Flattening the Curve: South Korea's Rapid and Massive Diagnosis of the COVID-19 Infection. The American Review of Public Administration, 50(6-7).

Jakobson, M.L., \& Leif Kalev, L. (2020). COVID-19 Crisis and Labor Migration Policy: A Perspective From Estonia. Frontiers in Political Science.

Jenkins, L.M. (2020, May 1). Emergency Managers Hope Pandemic Lessons Will Apply to Climate Preparedness. Morning Consultant. Retrieved from:

https://morningconsult.com/2020/05/01/emergency-management-climate-change-response/

Jenkins-Smith, H., Nohrstedt, D., Weible, C. M., \& Ingold, K. (2017). The Advocacy Coalition Framework: An overview of the research program. In C. M. Weible \& P. A. Sabatier (Eds.), Theories of the policy process (4th ed., pp. 135-171). Boulder, CO: Westview Press.

Johns Hopkins University. (2021). Coronavirus Resource Center. Retrieved from: https://coronavirus.jhu.edu/data.

Jones, M. D., \& Jenkins-Smith, H.C. (2009). Trans-Subsystem Dynamics: Policy Typography, Mass Opinion, and Policy Change. Policy Studies Journal, 37(1): 37-58.

Kelly, H. (2011). The classical definition of a pandemic is not elusive. Bulletin of the World Health Organization, 89(7), 540-541.

https://doi.org/10.2471/BLT.11.088815

Kingdon, J.W. (1984). Agendas, Alternatives, and Public Policies. Boston, MA: Little, Brown, \& Co.

Kingdon, J.W. (2003). Agendas, Alternatives, and Public Policies, 2nd ed. New York, NY: AddisonWesley Educational Publishers.

Lawlor, A., \& Crow, D.A. (2018). Policy Narratives of Wildfire and Drought Risk in Canada and the U.S. Policy Studies Journal, 46(4), 843-867.

Lawrence, R., \& Birkland, T.A. (2004). Guns, Hollywood, and school safety: Defining the schoolshooting problem across public arenas. Social Science Quarterly, 85(5),1193-1207.

May, P.J. (1992). Policy learning and failure. Journal of Public Policy, 12(4),331-354.

May, P. J., \& Jochim, A. E. (2013). Policy regime perspectives: Policies, politics, and governing. Policy Studies Journal, 41(3), 426-452.

https://doi.org/10.1111/psj.12024

May, P.J., Sapotichne, J., \& and Workman, S. (2009). Widespread policy disruption: Terrorism, public risks, and homeland security. Policy Studies Journal, 37(2), 171-194.

May, Peter J., Workman, S., \& Jones, B.D. (2008). Organizing attention: Responses of the bureaucracy to agenda disruption. Journal of Public Administration Research and Theory, 18, 517-541.

McConnell, A. (2010a). Policy success, policy failure and grey areas in-between. Journal of Public Policy, 30(3), 345-362.

https://doi.org/10.1017/S0143814X10000152

McConnell, A. (2010b). Understanding policy success: Rethinking public policy. New York, NY and London: Macmillan International Higher Education.

Monteblanco, A.D. (2021). The COVID-19 pandemic: A focusing event to promote community midwifery policies in the United States. Social Sciences \& Humanities Open,3(1).

Nohrstedt, D. (2010). Do Advocacy Coalitions Matter? Crisis and Change in Swedish Nuclear Energy Policy. Journal of Public Administration Research and Theory, 20,309-333. 
O'Donovan, K. (2017). An assessment of aggregate focusing events, disaster experience, and policy change. Risk, Hazards \& Crisis in Public Policy, 8(3), 201-219.

Olshan, J. (2020, March 29). Everything is insane. Everything is normal-The key to making sense of these dizzying times. MarketWatch. Retrieved from:

https://www.marketwatch.com/story/how-to-make-sense-of-this-dizzying-news-cycle-while-stillsheltering-in-place-2020-03-25.

Ornstein, N. (2020, March 13). Congress Desperately Needs a Contingency Plan: What will happen if lawmakers can no longer meet because of the coronavirus? The Atlantic. Retrieved from: https://www.theatlantic.com/ideas/archive/2020/03/congress-needs-contingency-plan-rightnow/607933/.

Patel, A., \& Jernigan, D.B. (2020). Initial public health response and interim clinical guidance for the 2019 novel coronavirus outbreak — United States, December 31, 2019-February 4, 2020. Morbidity and Mortality Weekly Report (MMWR), 69(5): 140-146.

Pralle, S.B. (2009). Agenda-setting and climate change. Environmental Politics 18(5): 781-799.

Rebelo, S. (2020, July 26). Covid-19 will permanently change the world's economy. CNN.

Retrieved from: https://www.cnn.com/2020/07/26/perspectives/sergio-rebelo-imf-covid-19-global-economy/index.html

Reville, P. (2020, April 9). Coronavirus gives us an opportunity to rethink K-12 education. The Boston Globe. Retrieved from:

https://www.bostonglobe.com/2020/04/09/opinion/coronavirus-gives-us-an-opportunity-rethink-k-12-education/

Reynolds, L. (2020). The COVID-19 Pandemic Exposes Limited Understanding of Ageism. Journal of Aging \& Social Policy, 32(4-5), 499-505.

Roberts, P. (2009). An Unnatural Disaster. Administration \& Society, 41(6), 763-769.

https://doi.org/10.1177/0095399709345628

Sabatier, P. A. (1988). An advocacy coalition framework of policy change and the role of policyoriented learning therein. Policy sciences, 21(2), 129-168.

Sabatier, P., \& Jenkins-Smith, H.C. (1993). Policy Change and Learning: An Advocacy Coalition Approach. Boulder, CO.: Westview Press.

Stone, D.A. (1989). Causal stories and the formation of policy agendas. Political Science Quarterly,104(2),281-300.

Tully-McManus, K. (2020, March 20). Access to House office buildings limited as return from recess is delayed, staff work from home. Roll Call. Retrieved from:

https://www.rollcall.com/2020/03/20/access-to-house-office-buildings-limited-as-return-fromrecess-is-delayed-staff-work-from-home/

Verhaeghe, PP., \& Ghekier A. (2020). The impact of the COVID-19 Pandemic on Ethnic Discrimination on the Housing Market. European Societies.

Weaver, D., McCombs, M., \& Shaw, D. L. (2004). Agenda-setting research: Issues, attributes, and influences. In L. Lee Kaid (Ed.), Handbook of political communication research (Chapter 10). New York, NY: Routledge.

Wee, S., \& Wang, V. (2020, January 21). China Grapples With Mystery Pneumonia-Like Illness. New York Times. Retrieved from:

https://www.nytimes.com/2020/01/06/world/asia/china-SARS-pneumonialike.html, accessed October 4, 2020. 
Weible, C.M, Nohrstedt, D., Cairney, P., Carter, D.P., Crow, D.A., Durnová, A.P., Heikkila, T., Ingold, K., McConnell, A., \& Stone, D. (2020). COVID-19 and the Policy Sciences: Initial Reactions and Perspectives. Policy Sciences, 53, 225-241.

Wheeldon, J., \& McBrien, A. (2014). (Mis) Representing the 2008 Prorogation: Agendas, Frames, and Debates in Canada's Mediacracy. Canadian Journal of Communication, 39(3).

https://doi.org/10.22230/cjc.2014v39n3a2782

Wolfe, M., Jones, B.D., \& Baumgartner, F. (2013). A Failure to communicate: Agenda setting in media and policy studies. Political Communication, 30(2), 175-192.

Wood, R.S. (2006). Tobacco's Tipping Point: The Master Settlement Agreements as a Focusing Event. Policy Studies Journal, 34(3), 419-436.

Yin, R. K. (2017). Case study research and applications: Design and methods. (6th ed.). Los Angeles, CA: Sage.

Zenko, M. (2020, June 5). “The United States Will Learn Nothing From the Pandemic.” Foreign Policy. Retrieved from:

https://foreignpolicy.com/2020/06/05/coronavirus-pandemic-covid-lessons-united-states-9-11/. 